\title{
Adult-onset nemaline myopathy
}

INSERM

\section{Source}

INSERM. (1999). Orphanet: an online rare disease and orphan drug data base. Adultonset nemaline myopathy. ORPHA:171442

Adult-onset nemaline myopathy is a rapidly progressive type of nemaline myopathy (NM; see this term) characterized by a very late onset. 